\title{
Book Review Raising Venture Capital for the Serious Entrepreneur
}

Michele K. Masterfano

Dermot Berkery, Raising Venture Capital for the Serious

Entrepreneur, New York: McGraw-Hill, 2008, \$49.95

$R$ aising Venture Capital for the Serious Entrepreneur is a fascinating journey through the world of venture finance. It provides an interesting, even absorbing view into the arcane world of how venture capitalists determine what companies they will finance, how they decide on the level of investment, and what they expect in return. It further provides important tips for entrepreneurs as they begin their planning for equity financing and the negotiations with VCs for that financing.

The book is divided into five parts, with each part moving us through the equity financing process. Part I provides the basics of how an entrepreneur should prepare for equity financing, covering such topics as developing a map of what the author calls stepping-stones: What milestones can and will be achieved with the financing sought? Berkery points out that venture capitalists will more than likely stage their investment, and they will expect the entrepreneur to meet specific objectives (stepping-stones) at each point of investment. There is also a discussion of $\mathrm{J}$ curves and peak cash needs, something that many entrepreneurs have most likely never even heard of, let alone considered.

The second section of the book focuses on actually raising the financing, covering such topics as how one determines the amount of money needed and writing a convincing business plan. It also covers how venture capital firms are structured, what types of investors put money in these firms, and more importantly, how VC funds determine expected returns, both from individual investments and for the fund itself. There is very important information in this chapter in particular for entrepreneurs; it is quite helpful to understand how venture capitalists work before approaching one or more for possible investments.

Almost every entrepreneur quivers or outright shakes when asked what he or she believes their company's premoney valuation is. It is an almost impossible question to answer, and there is a huge risk in being the first to put a value on the table. Part III of this book, however, takes some of the mystery out of this task. There is an excellent explanation as to why traditional valuation methodologies, those we've all learned in our college finance classes, do not work, as well as the provision of ways a company can maximize its valuation. The explanation of the valuation process is very helpful for all company owners, whether they are looking for an equity investment or just considering selling their business at some point in the future.

Another area that is fully explained yet is generally a mystery to entrepreneurs is found in Part IV, which provides a good level of detail on negotiating deal terms. There is a fine explanation of term sheets and the often-inscrutable terminology used in them. Many company owners will want to become familiar with terms such as exit preferences, antidilution requirements, ratchets, tagalong rights, and so forth. There is also a very informative section on how one can allocate control between the company's management and its investors, as well as on how to align the interests between management and investors through the use of option pools, founders stock, and other arrangements.

Finally, Part V provides exercises on term sheet negotiations. This is quite helpful for managers who have never seen a term sheet, and allows them to try their hand at figuring how best to keep as much control of their company as possible when entering into an agreement with a VC. This is accomplished through mini-cases that present typical terms presented to entrepreneurs, followed by questions that readers should answer in order to understand what is going on, what the various parties are attempting to achieve, and what terms might be more negotiable than others.

Raising Venture Capital is an excellent resource for entrepreneurs as well as those who wish to pursue a career in venture capital. Mini-cases are presented throughout the book, not just in the final section, that allow you to work through the problems presented yourself and to further your understanding of the concepts presented. There are also several tips for entrepreneurs highlighted throughout. The book is quite easy to read, and even though it presents many esoteric concepts, they are examined in a way that any business person can understand them.As the author is a venture capitalist himself, there is a high level of credibility in what is presented. 
This is an excellent resource not only for entrepreneurs, but also for both undergraduates and graduate students in entrepreneurial finance classes. It could either be assigned as a textbook itself, or simply be used as a resource for the professor from which to develop lectures. As mentioned previously, it can also be used as a primer for those who wish to embark on a career in venture capital, and also for those who wish to become private investors themselves. Naturally, those entrepreneurs who are preparing to seek outside investments will find this a thorough resource and potent ammunition in their arsenal as they begin negotiations for equity financing from sophisticated investors.

\section{About the Author}

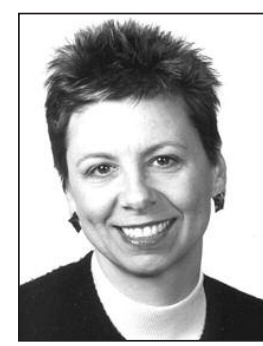

MiChele K. Masterfano (michele@masterfano.com) is a clinical assistant professor in the Management Department of the LeBow School of Business at Drexel University. She teaches strategy and entrepreneurship, and has recently published a book, Effective Business Planning:A Structured Approach that is in use in her business and new venture planning classes. Prof. Masterfano has also been working with entrepreneurial firms for more than 10 years, after a long career launching new products and new divisions for AT\&T. She focuses primarily on business and operational planning, but has also been known to step in and help lead growing businesses on an interim basis. She holds a DBA in marketing and management from Argosy University Sarasota. 